\title{
Increasing Population Knowledge: The Comparation of Problem Solving Learning Methods with Conventional Methods
}

\author{
Nurdin $^{1 *}$ iD \\ ${ }^{1}$ Postgraduate Faculty, University of Indraprasta PGRI, Jakarta, Indonesia \\ *Corresponding author: dr.nurdin3067@yahoo.com
}

\section{Abstract}

This study aims to analyze the effect of teaching methods using problem solving and conventional on population knowledge. The research was conducted experimentally with a $2 \times 2$ factorial design on 80 students consisting of 40 students having a high attitude, and 40 students having a low attitude at the Junior High School 2 Tambun Selatan-Bekasi. Data collection regarding population knowledge was carried out using an objective test instrument with the answer choices True (B) with a score of 1 and False (S) with a score of 0 . The data were analyzed by means of two-way analysis of variance, and the Tukey test. Research results There are differences in population knowledge learning outcomes between students who are given problem solving teaching methods and students who are given conventional teaching methods; There is an interaction between teaching methods and students' attitudes towards population knowledge; Study groups that have high and low attitudes have higher population knowledge learning outcomes when given problem solving teaching methods compared to students who are given conventional teaching methods. The implication is that teachers in teaching must always build a high attitude in the classroom so that positive interactions occur in the teaching and learning process by using various learning methods.

Keywords: Problem Solving, Conventional, Population Knowledge

\begin{tabular}{|c|c|}
\hline History: & Publisher: Undiksha Press \\
\hline Received : April 10, 2021 & Licensed: This work is licensed under \\
\hline Revised : April 11, 2021 & a Creative Commons Attribution 3.0 License \\
\hline Accepted : June 21, 2021 & (c) (†) () \\
\hline Published : July 25, 2021 & (C) $\mathrm{BY}_{\mathrm{SA}}$ \\
\hline
\end{tabular}

\section{INTRODUCTION}

The main population problem faced by developing countries including Indonesia is a relatively large population with low quality human resources (Naik et al., 2020; Puspitasari, 2018). Indonesia's population ranks third largest in Asia and fourth in the world after the People's Republic of China, India, and the United States (Mahdalena \& Sain, 2020; Rosidah, 2016). In addition, Indonesia has an average population density and growth rate that is higher than any other country in the world. The average population density in the world is only 45 people $/ \mathrm{km} 3$ while the population density in Indonesia is 106 people $/ \mathrm{km} 3$. World population growth is $1.2 \%$ per year, while the population growth rate in Indonesia is $1.35 \%$ per year. The importance of knowledge about population which is usually taught in Geography subjects for people around the world and Indonesia is something that must be a common concern. However, in reality knowledge of population is still less attractive to students in schools so that an innovative teaching method is needed or using certain technologies to increase knowledge of geography, especially population (Favier \& Van Der Schee, 2014; Ji \& Grishman, 2011). This condition also occurs in developed countries such as Germany, where survey results show students are less interested in knowing about population in geography or social science subjects at school (Gans et al., 2018).

Population is something related to the population which includes basic information about the number, distribution, density, and growth (Strulik \& Weisdorf, 2008). Population knowledge is the basis given to students about population problems (Maftuchah, 2000). Population growth between developed countries and developing countries has differences. Developed countries tend to reduce population growth while developing countries have 
population growth continues to increase (Ji \& Grishman, 2011). It is further explained that population density is the result of calculating the number of inhabitants per square kilometer. The population is a group of individuals who can be divided according to differences in location, culture, and nationality (Wright \& Nebel, 2000). Population knowledge must be taught to students starting at the primary and secondary education levels. This is evidenced by the existence of the theme of population learning starting from elementary school and continuing at the junior secondary level (Nora, 2018). However, if it is not supported by the teacher's ability to master various learning methods, it will be less than optimal (Prasetyono et al., 2021). This will result in the level of achievement of educational goals in the teaching and learning process that has been determined.

The teaching method is a method used by teachers to deliver teaching materials to students in the classroom on certain topics that are arranged logically and regularly (Wilson et al., 2017). This means that teaching is active participation with students in forming knowledge, making meaning, seeking clarity, and holding justifications. There are various learning methods that can be used by teachers in teaching social sciences in the 2013 Curriculum, including problem solving and conventional methods (Ramdayana et al., 2020). Problem-based teaching is a very effective approach to teaching high-level thinking processes, helping students process the information they already have, and build their own knowledge of the social and physical world around them (Ibrahim \& Nur, 2000). Problem solving teaching methods have 3 positive impacts, namely (1) increasing students' positive attitudes towards the problems they face; (2) encourage students to participate actively; and (3) expose students to challenging skills so that students understand problem solving and analytical thinking (Barak \& Mesika, 2007). Assignment questions that are problem solving in population knowledge can be given in the form of individuals or groups. Direct involvement of students in the learning process using problem solving methods requires higher-order thinking skills (Koichu, 2020). Learning that requires higher-order thinking skills will develop the process skills of students' thinking patterns. A good way to present a problem is to use an interesting event so that it can create a mystery and a desire to solve the problem. The thinking process in solving population problems requires high thinking skills that will organize strategies in mind that are in accordance with the data and problems encountered. Therefore, it can be understood that the mastery of solving population problems must first master the lower cognitive aspects, namely: memory, understanding, and application (Nur, 2000; Panek et al., 2006).

However, there are still many teachers who teach using conventional methods. The conventional method that is often used by teachers in the teaching and learning process is the lecture method (Bloomfield et al., 2010). Lectures are the only conventional method and are still used in teaching and learning strategies (Gulo, 2002). The lecture method is a popular method and is widely used by teachers, besides being easy to present, it also does not require much media with teaching procedures to provide information aimed at making teaching participants ready to accept instructional learning (Aziz \& Hossain, 2010). The teacher simply speaks giving teaching materials actively and students listen interspersed with questions and answers or assignments. The characteristics of the lecture method are that the teacher speaks continuously in front of the class, while the students are listeners so that it is only one-way (Wilson et al., 2017). Because the lecture method is widely used by teachers, in its delivery in class it is recommended to: (1) attract the attention of participants with movements and facial expressions, (2) provide examples that inspire and create a lively atmosphere, and (3) provide case examples related to topics studied (Sanaie et al., 2019). The teaching-learning process in the classroom using the lecture method, the teacher monitors students and provides individual guidance for students who have difficulty doing assignments. Whether or not students are interested in the subject or when the teacher 
explains using a certain learning method can be seen in the attitude during class. If interested, students will focus, take notes, ask questions and draw conclusions using their own language. On the other hand, if they are not interested, students will chat, sleepy, bored, look for their own activities and do not understand the material presented by the teacher (Mangen et al., 2019).

Attitude is a system of cognition, feelings, and a person's tendency to act on objects around him which consists of 3 components, namely: a cognitive component which means a person's beliefs about the object of attitude, the object of the attitude is an individual assessment of the object in question; the feeling component which means the extent to which the object has a pleasant or unpleasant feeling; and the tendency component of individual readiness to behave (Heyder et al., 2020). Attitudes are formed from past experiences of an object, situation and mental state when receiving or organizing information (Pehlivan \& Köseoglu, 2011). So it can be seen if the attitude can be positive or negative. Students' attitudes towards population knowledge are a person's psychological response to certain objects, both in the form of objects and events that occur from outside themselves. Attitude is an internal ability that plays a role in taking action (Oruç \& Teymuroğlu, 2011). People who have an attitude, are able to choose firmly between several possibilities. Someone who has a positive affection for a psychological object can be said to like the object. Someone who has a negative affection for a psychological object can be said to dislike the object.

At the secondary education level, population knowledge must begin to be taught in more depth. This is because at that time the individual enters early adolescence who must be more sensitive to population conditions. Junior High School (JHS) included in the secondary education level has a strategic position in providing the foundation for the next level of child development. However, because of the condition that the students are less interested in population knowledge, the teacher must use innovative methods. Therefore, the research in this article aims to determine the differences in population knowledge learning outcomes from teachers who teach using the lecture method with problem solving methods when viewed from the attitudes of students.

\section{METHODS}

The study was conducted experimentally using a $2 \times 2$ factorial design. The experimental method used the dependent variable and the independent variable to determine whether there were differences in the control class and the experimental class (Saputra \& Prasetyono, 2020). The dependent variable in this study is population knowledge, while the independent variables include teaching methods as treatment variables and student attitudes as attribute variables. This research was conducted at JHS Negeri 2 Tambun Selatan-Bekasi, West Java Province for 6 months, from September to February 2019/2020. The research subject was a group of students consisting of 80 students consisting of 40 students having a high attitude, and 40 students having a low attitude. Data collection regarding population knowledge was carried out with an objective test instrument with the answer choices True (B) with a score of 1 and False $(\mathrm{S})$ with a score of 0.

\section{RESULTS AND DISCUSSION}

\section{Results}

Data analysis begins with normality and homogeneity tests between groups of research subjects. Based on the Lilliefors test at the level of 0.05 , it shows that the overall group of research subjects has a normal distribution. Then continued with the homogeneity test at the level of 0.05 indicating that the overall group of research subjects had no different 
variances. Furthermore, the Tukey test to determine the effect of interaction between independent variables on population knowledge using two-way analysis of variance (twoway ANOVA). Data processing in testing research hypotheses inferentially tested using analysis of variance (ANOVA). The test results are presented in Table 1.

Table 1. Summary of Two-way Analysis of Variance

\begin{tabular}{lcllll}
\hline Source of Variance & Dk & \multicolumn{1}{c}{ JK } & RJK & $\mathbf{F}_{\mathbf{h}}$ & Information \\
\hline Between Columns (A) & 1 & 15.49 & 15.49 & $6.92 *)$ & Sig. \\
Between Rows (B) & 1 & 9.82 & 9.82 & 5.081 & Non. Sig. \\
Interaction ( A x B) & 1 & 175.66 & 175.66 & $58.374 * *)$ & Sig. \\
\hline \multicolumn{1}{c}{ Inside of } & 76 & 578.43 & 7.611 & & \\
\hline \multicolumn{1}{r}{ Total } & 79 & 517 & & & \\
\hline
\end{tabular}

Differences in population knowledge learning outcomes between students who were given problem solving teaching methods and students who were given conventional teaching methods. The $F_{t}$ value with a level of $5 \%$ and the 1-party test obtained the result of 2.87 . While the $F_{t}$ value with a level of $5 \%$ and the 1-party test, the result is 2.87 . While the results of the analysis of variance (ANAVA) $\alpha=0.05$ based on table 2, the results obtained are 6.92. Then $F_{h}=6.92>F_{t}=2.87$. This means that $\mathrm{H}_{0}$ is rejected. So it can be concluded that there are differences in population knowledge learning outcomes between students who are given problem solving teaching methods and students who are given conventional teaching methods. There is an interaction between teaching methods and student attitudes towards population knowledge learning outcomes. The $\mathrm{F}_{\mathrm{t}}$ value with a level of $5 \%$ and the 1-party test obtained the result of 2.87. While the results of the analysis of variance (ANOVA) $\alpha=0.05$ based on table 2 obtained the results of 58.374. Then $F_{h}=58.374>F_{t}=2.87$. This means that $\mathrm{H}_{0}$ is rejected. So it can be concluded that there is an interaction between teaching methods and student attitudes towards the learning outcomes of population knowledge. Differences in population knowledge learning outcomes between students who are given problem solving teaching methods and population knowledge learning outcomes between students who are given conventional teaching methods, for students who have high attitudes.

The results of data analysis using the Tukey test, the learning outcomes of population knowledge given the problem solving teaching method are higher than the population knowledge learning outcomes for students who are given conventional teaching methods. The result is the calculated $\mathrm{Q}$ value $=8.13>$ the table $\mathrm{Q}$ value $(0.05: 4: 76) 5.34$ this means that $\mathrm{H}_{0}$ is rejected and $\mathrm{Ha}$ is accepted. This means that there are differences in population knowledge learning outcomes given problem solving teaching methods with population knowledge learning outcomes given conventional teaching methods, for students who have high attitudes. Judging from the average score, it can be concluded that the average score of population knowledge learning outcomes given problem solving teaching methods is 17.56 higher than the average population knowledge learning outcomes given conventional teaching methods $=16.49$. For students who have a high attitude. So group (A1B1) $>$ group (A2B1).

Differences in population knowledge learning outcomes between students who are given problem solving teaching methods and population knowledge learning outcomes between students who are given conventional teaching methods, for students who have low attitudes.The results of data analysis using the Tukey test, the results of learning population knowledge for students who are given problem solving teaching methods are lower than the results of learning population knowledge for students who are given conventional teaching methods giving a value of $\mathrm{Q}$ count $=7.15>\mathrm{Q}$ table value $(0.05: 4: 76)=5.34$ this means that 
$\mathrm{H}_{0}$ is rejected and $\mathrm{Ha}$ is accepted. So that it can be interpreted that there are differences in population knowledge learning outcomes between students who are given problem solving teaching methods and population knowledge learning outcomes given conventional teaching methods, for students who have low attitudes. Judging from the average score, it can be concluded that the average score of population knowledge learning outcomes given the problem solving teaching method is $\mathbf{1 5 . 6 2}$ lower than the average population knowledge learning outcome score between students who are given conventional teaching methods of 16.13. For students who have a low attitude. Thus group (A1B2) < group (A2B2).

\section{Discussion}

There are differences in population knowledge learning outcomes between students who are given problem solving teaching methods and students who are given conventional teaching methods. This finding can be explained by the results of other studies which state that the use of problem-solving learning methods has better learning outcomes when compared to conventional methods in Economics subjects at the high school level (Prasetyono et al., 2018). This difference in learning outcomes arises because the problemsolving method succeeds in presenting problems that interest and create a mystery so that a desire arises to find a solution to the problem (Albay, 2019). The thinking process of students when teachers use problem solving methods in teaching population knowledge requires students' cognitive thinking skills, so that they organize the chosen strategy according to the problems they face (Ibrahim \& Nur, 2000). Therefore, in mastering population knowledge, students must first master the lower cognitive aspects, namely knowing.

A teacher teaching means participation with students in forming knowledge, making meaning, seeking clarity, and providing justification. Referring to the statement, students who are given problem solving teaching methods are easier to understand population material because students need a thinking process so that learning outcomes are better (Rapi, 2016). Conventional learning such as lectures is a teaching procedure that provides information aimed at making teaching participants ready to accept instructional learning (Saguni, 2013). Students who are given conventional teaching methods only receive information provided by the teacher so that learning outcomes are inadequate. When students receive knowledge from the teacher, it is not necessarily that students will remember, understand and be able to implement that knowledge. The process of processing information and knowledge needs to be tied up in students' minds by using problem solving methods (Nora, 2018). This statement is the same as population learning at the secondary education level. Based on the concept difference between the problem solving method and the lecture when used by the teacher in teaching, the learning outcomes are different. Problem solving methods stimulate students to think creatively and use new ways to answer or do assignments given by the teacher. There is an interaction between teaching methods and students' attitudes towards population knowledge.

Teachers in carrying out the learning process can be carried out well, it is necessary to arrange teaching materials according to the needs of students (Prasetyono et al., 2020). The arrangement of these structured teaching materials becomes the teacher's reference in teaching well in the classroom. One of the criteria for using the right teaching method when teaching by the teacher is the enthusiasm of students that causes interaction in the teaching and learning process (Heyder et al., 2020). The learning method with lectures can provide examples of cases related to the topic being studied so that it creates interaction in the classroom (Woschank \& Pacher, 2020). The teaching approach to problem solving can encourage students to participate actively which allows knowledge to increase which is characterized by teacher-student interactions (Koichu, 2020). Knowledge is obtained from the interaction between the stimulus and active thinking and is stored in the student's 
memory. A person's knowledge is the result of selectively organized learning from a number of facts, information about the principles he has from various experiences with other people (Ji \& Grishman, 2011). Knowledge is the result of the interaction between the stimulus and active thinking about a particular object and stored in memory. Piaget stated that knowledge is not taken for granted from the teacher, but the students themselves must organize, think about, and shape that knowledge so as to lead to understanding (Suparmo, 2001). So to form one's knowledge, a good teaching method is needed so that there is interaction between students and educators.

The higher the interaction that occurs between the teacher and the students means that it is almost certain that students are happy to learn the material and understand the material presented (Chang et al., 2015). Interaction is also one of the priority indicators that must be achieved in the use of other learning methods. The use of jigsaw learning methods, discussions or other cooperative learning aims to stimulate student curiosity so that interactions between teachers and students appear in the classroom ((Alrassi \& Mortensen, 2020). So that every teacher is expected to always use teaching methods that can lead to intensive interaction with student attitudes. This is what causes the interaction between teaching methods and student attitudes towards population knowledge at SMP Negeri 2 Tambun Selatan. Study groups of students who have high attitudes have higher population knowledge learning outcomes when taught using problem solving methods compared to students who are taught using conventional teaching methods. The results of this study corroborate the results of previous research which concludes that the learning outcomes of students taught by the problem-solving method are higher than those of students who are taught by the lecture method (Putri, 2018). Students who have a high attitude in learning means that they are successful in managing their own cognitive, affective and psychomotor thinking systems which are reflected in their daily actions in class. The system of thought patterns created in students creatively encourages students to understand in the learning process of population knowledge (Sung, 2017). To be able to create creative student thinking patterns, it is necessary to use appropriate learning methods.

Teachers who teach using problem solving methods are a very effective approach to teach higher-order thinking processes, help students process the information they already have, and build their own knowledge of the social and physical world around them (Nur, 2000). Teaching approaches regarding problem solving can increase students' positive attitudes and encourage students to actively participate in the problems they face (Widodo \& Kartikasari, 2017). Students who have a high attitude are easier to receive information about facts that are arranged regularly so that they have meaning and can be applied (Yearworth et al., 2013). Conventional teaching such as lectures has a characteristic that the teacher talks continuously in front of the class, while the students are listeners (Widodo \& Kartikasari, 2017). Students who have a low attitude find it difficult to absorb the material provided by the teacher so that population knowledge is less than optimal. Population knowledge in the teaching and learning process requires interaction from teachers to students because population knowledge is part of social science lessons (Okuducu \& Aral, 2017). Active interaction between teachers and students makes students explore the deepest meaning of a science needed in the understanding process. Study groups that have a high attitude of population knowledge learning outcomes in students who are given problem solving teaching methods are higher than the population knowledge learning outcomes of students who are given conventional teaching methods.

Study groups of students who have low attitudes have higher population knowledge learning outcomes when taught using problem solving methods compared to students who are taught using conventional methods. The results of this study strengthen the results of previous studies which stated that the learning outcomes of students who were taught by 
problem solving methods were higher than those of students who were taught by the lecture method on mathematics subjects (Aziz \& Hossain, 2010). Although the results of the research were carried out on different subjects, the learning process was carried out by improving attitudes first when learning in class. After the student's attitude appears that causes interaction between the teacher and the student, the teacher then conveys the material. This process can be assessed as the same as the student learning process in the classroom using the population knowledge problem solving method. Unlike the case with using the discussion method which is the development of the lecture method. Teachers and students can interact with each other so that it creates understanding for students but does not cause a high attitude (Amaliah \& Fadhil, 2014). A high attitude arises because students are curious about the topic or problem that occurs (Şengül \& Katranci, 2014). Referring to the view of Thurstone in (Colton \& Covert, 2007), it is stated that someone who has negative feelings towards an object is most likely to dislike it. Students' dislike of certain subjects is reflected in the attitude displayed. This results in low interaction in the learning process in the classroom.

Students who have a low attitude of being taught can be improved with problem solving learning methods (Albay, 2019). Students will feel curious if they are taught with problem solving methods. This is what can improve students' attitudes in interacting and increase students' creative thinking. have difficulty understanding the material being taught so that population knowledge is inadequate. Students who have a low attitude are taught by problem solving methods clearly more easily absorb the material taught by the teacher so that their population knowledge is better (Helmi et al., 2012). So it can be concluded if students who are taught by teachers using problem solving methods have better learning outcomes than students who are taught using conventional methods. This finding implies that teachers in teaching must always build a high attitude in the classroom so that positive interactions occur in the teaching and learning process using various learning methods. The limitation of this research is that it was only conducted at the junior high school level and on population knowledge, while other levels of education such as high school also need to be researched. Besides that, it is also necessary to do natural science or mathematics subjects. It will be more interesting and may get mixed results if it is implemented at higher or basic education levels with different knowledge.

\section{CONCLUSION}

There are differences in the learning outcomes of population knowledge between students who are taught by teaching problem solving methods and students who are taught by conventional teaching methods. Attitude is one of the main indicators in the success of teaching population knowledge at the junior high school level. Study groups of students who have high and low attitudes have higher population knowledge learning outcomes if they are taught by teachers who use problem solving teaching methods compared to students who are taught using conventional teaching methods. Teachers in teaching population knowledge must always build a high attitude in students in order to create positive interactions in the learning process.

\section{REFERENCES}

Albay, E. M. (2019). Analyzing the effects of the problem solving approach to the performance and attitude of first year university students. Social Sciences \& Humanities Open, 1(1). https://doi.org/10.1016/j.ssaho.2019.100006.

Alrassi, J., \& Mortensen, M. (2020). Jigsaw Group-Based Learning in Difficult Airway Management: An Alternative Way to Teach Surgical Didactics. Journal of Surgical 
Education, 63(1). https://doi.org/10.1016/j.jsurg.2020.02.003.

Amaliah, R. R., \& Fadhil, A. (2014). Penerapan Metode Ceramah dan Diskusi Dalam Meningkatkan Hasil Belajar PAI di SMA Negeri 44 Jakarta. Studi Al-Qur'an; Membangun Tradisi Berfikir Qur'an, 10(2), 119-131. http://journal.unj.ac.id/unj/index.php/jsq/article/view/4441.

Aziz, Z., \& Hossain, M. A. (2010). A comparison of cooperative learning and conventional teaching on student's achievement in secondary mathematics. Procedia - Social and Behavioral Sciences, 9, 53-62. https://doi.org/10.1016/j.sbspro.2010.12.115.

Barak, M., \& Mesika, P. (2007). Teaching methods for inventive problem-solving in junior high school. Thinking Skills and Creativity, 2(1), 19-29. https://doi.org/10.1016/j.tsc.2006.10.002.

Bloomfield, J., Roberts, J., \& While, A. (2010). The effect of computer-assisted learning versus conventional teaching methods on the acquisition and retention of handwashing theory and skills in pre-qualification nursing students: A randomised controlled trial. International Journal of Nursing Studies, 47(3), 287-294. https://doi.org/10.1016/j.ijnurstu.2009.08.003.

Chang, Y.-L., Wu, S.-C., \& Wu, H.-H. (2015). They are Learning: Changes through Teacher Professional Development of Inquiry Curriculum Design and Implementation. Procedia - Social and Behavioral Sciences, 177, 178-182. https://doi.org/10.1016/j.sbspro.2015.02.375.

Colton, D., \& Covert, R. W. (2007). Designing and Social Research and Instruments for Constructing Evaluation.

Jossey-Bass. https://doi.org/10.1017/CBO9781107415324.004.

Favier, T. T., \& Van Der Schee, J. A. (2014). The effects of geography lessons with geospatial technologies on the development of high school students' relational thinking. Computers and Education, 76, 225-236. https://doi.org/10.1016/j.compedu.2014.04.004.

Gans, P., Hemmer, I., Hemmer, M., \& Miener, K. (2018). The Perception of Geography Among The German Population Findings of A Representative Survey. Erdkunde, 72(1), 23-40. https://www.jstor.org/stable/26411578.

Gulo, W. (2002). Strategi Belajar Mengajar. Gramedia Widiasarana Indonesia.

Helmi, S. A., Yusof, K. M., \& Phang, F. A. (2012). Enhancement of engineering students' problem solving skills through cooperative problem-based learning. International Journal of Engineering Education, 56, 737-746. https://doi.org/10.1016/j.sbspro.2012.09.711.

Heyder, A., Südkamp, A., \& Steinmayr, R. (2020). How are teachers' attitudes toward inclusion related to the social-emotional school experiences of students with and without special educational needs? Learning and Individual Differences, 77(July 2018). https://doi.org/10.1016/j.lindif.2019.101776.

Ibrahim, M., \& Nur, M. (2000). Pengajaran Berdasarkan Masalah. Unesa Universitas Press.

Ji, H., \& Grishman, R. (2011). Knowledge Base Population: Successful approaches and challenges. ACL-HLT 2011 - Proceedings of the 49th Annual Meeting of the Association for Computational Linguistics: Human Language Technologies, 11481158.

Koichu, B. (2020). Problem posing in the context of teaching for advanced problem solving. International Journal of Educational Research, 102(July). https://doi.org/10.1016/j.ijer.2019.05.001.

Maftuchah, Y. (2000). Pendidikan Kependudukan dan Etika Lingkungan. Lembaga Studi Inovasi Pendidikan.

Mahdalena, S., \& Sain, M. (2020). Meningkatkan Hasil Belajar Siswa Melalui Penerapan 
Model Pembelajaran Cooperative Script Pada Mata Pelajaran Ilmu Pengetahuan Sosial Kelas VA Siswa Sekolah Dasar Negeri 010 Sungai Beringin. Asatiza Jurnal Pendidikan, 1(1), 118-138.

Mangen, A., Hoel, T., Jernes, M., \& Moser, T. (2019). Shared, dialogue-based reading with books vs tablets in early childhood education and care: Protocol for a mixed-methods intervention study. International Journal of Educational Research, 97(March), 88-98. https://doi.org/10.1016/j.ijer.2019.07.002.

Naik, G., Chitre, C., Bhalla, M., \& Rajan, J. (2020). Impact of use of technology on student learning outcomes: Evidence from a large-scale experiment in India. World Development, 127, 104736. https://doi.org/10.1016/j.worlddev.2019.104736.

Nora, Y. (2018). Learning of Social Studies in Elementary School as a Medium to Strengthen Multicultural Education in The Curriculum Era 2013. SHS Web of Conferences, 42(94), 1-7. https://doi.org/10.1051/shsconf/20184200094.

Nur, M. (2000). Pengantar Teori Tes. P2LPTK.

Okuducu, M. B., \& Aral, M. M. (2017). Knowledge based dynamic human population models. Technological Forecasting and Social Change, 122(May), 1-11. https://doi.org/10.1016/j.techfore.2017.05.008.

Oruç, Ş., \& Teymuroğlu, B. (2011). The effects of using cartoon in teaching social sciences on attitudes of students against to social science course. Procedia - Social and Behavioral Sciences, 15, 3211-3215. https://doi.org/10.1016/j.sbspro.2011.04.273.

Panek, R. C., Deloney, L. A., Park, J., Goodwin, W., Klein, S., \& Ferris, E. J. (2006). Interdepartmental Problem-Solving as a Method for Teaching and Learning SystemsBased Practice. Academic Radiology, 13(9), 1150-1154. https://doi.org/10.1016/j.acra.2006.06.003.

Pehlivan, H., \& Köseoglu, P. (2011). The reflections of certain social factors concerning science high school students into their attitudes towards physics course. Procedia Social and Behavioral Sciences, 15, 605-608. https://doi.org/10.1016/j.sbspro.2011.03.148.

Prasetyono, H., Abdillah, A., Widiarto, T., \& Sriyono, H. (2018). Character-based Economic Learning Implementation and Teacher's Reinforcement on Student's Affective Competence in Minimizing Hoax. Cakrawala Pendidikan, 37(3), 426-435. https://doi.org/10.21831/cp.v38i3.21583.

Prasetyono, Hendro, Abdillah, A., Anita, T., Nurfarkhana, A., \& Sefudin, A. (2020). Identification of the Decline in Learning Outcomes in Statistics Courses Using the Chi-Squared Automatic Interaction Detection Method. Journal of Physics: Conference Series, 1490, 1-9. https://doi.org/10.1088/1742-6596/1490/1/012072.

Prasetyono, Hendro, Abdillah, A., Djuhartono, T., Ramdayana, I. P., \& Desnaranti, L. (2021). Improvement of teacher's professional competency in strengthening learning methods to maximize curriculum implementation. International Journal of Evaluation and Research in Education, 10(2), 720-727. https://doi.org/10.11591/ijere.v10i2.21010.

Puspitasari. (2018). Metode Pembelajaran Bermain Peran Pada Pembelajaran Bahasa Indonesia. Jurnal Cakrawala Pendas, I(1), 55-64. https://doi.org/https://www.researchgate.net/deref/http\%3A\%2F\%2Fdx.doi.org\%2F10 $.31949 \% 2 F j c p . v 1 i 1.347$.

Putri, E. (2018). Perbedaan Hasil Belajar Ekonomi Menggunakan Metode Problem Solving (Pemecahan Masalah) dengan Metode Ceramah Pada Siswa Kelas X IPS SMAN 3 Teladan Bukittinggi. Jurnal Pendidikan Ekonomi, 11(2), 99-106. http://journal2.um.ac.id/index.php/jpe/article/view/5174.

Ramdayana, I. P., Prasetyono, H., \& Rahman, N. V. T. (2020). Comparative Study Of Discussion And Question-Answer Learning Method To Improve Learning Outcomes 
Of Vocational High School Students. Jurnal PAJAR (Pendidikan Dan Pengajaran), $4(3)$, 597-607. https://scholar.archive.org/work/6rqahp2tzzhvlkqt23byyth47y/access/wayback/https:// pajar.ejournal.unri.ac.id/index.php/PJR/article/download/7990/pdf.

Rapi, N. K. (2016). Pengaruh Model Pembelajaran dan Jenis Penilaian Formatif Terhadap Hasil Belajar IPA Siswa SMPN. Cakrawala Pendidikan, 35(1), 69-79. https://repo.iainbatusangkar.ac.id/xmlui/bitstream/handle/123456789/8042/15090963 41657_8366-21320-1-PB.pdf?sequence=1.

Rosidah, A. (2016). Penerapan Media Pembelajaran Visual Untuk Meningkatkan Pemahaman Konsep Siswa Pada Mata Pelajaran Ips. Jurnal Cakrawala Pendas, 2(2). https://doi.org/10.31949/jcp.v2i2.499.

Saguni, F. (2013). Efektivitas Metode Problem Based Learning, Cooperative Learning Tipe Jigsaw, dan Ceramah Sebagai Problem Solving dalam Matakuliah Perencanaan Pembelajaran. Cakrawala Pendidikan, 32(2), 207-219. https://doi.org/10.21831/cp.v0i2.1478.

Sanaie, N., Vasli, P., Sedighi, L., \& Sadeghi, B. (2019). Comparing The Effect of Lecture and Jigsaw Teaching Strategies on The Nursing Students' Self-Regulated Learning and Academic Motivation: A Quasi-Experimental Study. Nurse Education Today, 79, 35-40. https://doi.org/10.1016/j.nedt.2019.05.022.

Saputra, S., \& Prasetyono, H. (2020). The Effect of Science Approach to The Activity of Learning Students In SMPN 25 Tangerang City. Jurnal PAJAR (Pendidikan Dan Pegajaran), 4(1), 20-30. https://doi.org/10.33578/pjr.v4i1.7910.

Şengül, S., \& Katranci, Y. (2014). Effects of Jigsaw Technique on Mathematics Self-Efficacy Perceptions of Seventh Grade Primary School Students. Procedia - Social and Behavioral Sciences, 116, 333-338. https://doi.org/10.1016/j.sbspro.2014.01.217.

Strulik, H., \& Weisdorf, J. (2008). Population, food, and knowledge: A simple unified growth theory. Journal of Economic Growth, 13(3), 195-216. https://doi.org/10.1007/s10887008-9033-7.

Sung, E. (2017). The influence of visualization tendency on problem-solving ability and learning achievement of primary school students in South Korea. Thinking Skills and Creativity, 26, 168-175. https://doi.org/10.1016/j.tsc.2017.10.007.

Suparmo, P. (2001). Teori Pengembangan Kognitif jean Piaget. Kanisius.

Widodo, S., \& Kartikasari, K. (2017). Pembelajaran Pemecahan Masalah Matematis Siswa Sekolah Dasar Dengan Model Creative Problem Solving (Cps). Prisma, 6(1). https://doi.org/10.35194/jp.v6i1.28.

Wilson, J. A., Pegram, A. H., Battise, D. M., \& Robinson, A. M. (2017). Traditional Lecture Versus Jigsaw Learning Method For Teaching Medication Therapy Management (MTM) Core Elements. Currents in Pharmacy Teaching and Learning, 9(6), 11511159. https://doi.org/10.1016/j.cpt1.2017.07.028.

Woschank, M., \& Pacher, C. (2020). Teaching and learning methods in the context of industrial logistics engineering education. Procedia Manufacturing, 51, 1709-1716. https://doi.org/10.1016/j.promfg.2020.10.238.

Wright, R. T., \& Nebel, B. J. (2000). Environmental Science. Prentice-Hall, Inc.

Yearworth, M., Edwards, G., Davis, J., Burger, K., \& Terry, A. (2013). Integrating problem solving and research methods teaching for systems practice in engineering. Procedia Computer Science, 16, 1072-1081. https://doi.org/10.1016/j.procs.2013.01.113. 